\title{
CLIMATE CHANGING IMPACT ON RICE PRODUCTION
}

\author{
Fitriani $^{1}$ \\ ${ }^{1}$ Agribisnis Jurusan Ekonomi dan Bisnis Politeknik Negeri Lampung \\ e-mail: $\underline{* 1 \text { fitriani@polinela.ac.id }}$
}

\begin{abstract}
Rice is the staple food of Indonesian society. The national rice production capability depends not only on the technical and economic aspects of production but also on the environmental carrying capacity, especially the availability of adequate rainfall and climate. The cyclical changes of extreme climate that occur affect the performance of national rice production. This study aims to determine the impact of extreme climate on national rice production. The research method used linear regression with El Nino (D1) and La Nina (D2) as extreme dummy extreme free variable and national rice production as its bound factor. The data used are based on BPS Indonesia with the duration of 1980-2011. The analysis shows that the presence of cyclically extreme climate has a significant effect on national rice production. Climate change has a negative and positive impact on rice production. El-Nino has a negative impact, while La Nina is the opposite. The difference in the size of the impact of climate change can be seen from the slope difference in the variable coefficient.
\end{abstract}

Key words: climate changing, El-Nino, La-Nina, production, rice

\section{Introduction}

Food sufficiency is important need for every nation. Independency on food production and distribution will establish self-determination of nation. As an autonomous nation, independency on food production, availability and distribution are very important. The lack of food resources is usually regarded as a weakness and, thus, puts the nation as dependent to other countries. Limited outcome of food production threats the nation's stability and its people's welfare as well. The staple food becomes political and strategic commodity. Then, every single government sets up strategic policy to regulate primary food to ensure everyone has an access to food as standard needs.

Most Indonesians consume rice as their staple food to meet their needs. Rice becomes strategic commodity. The community will be focused on anything including production, availability, distribution, and consumption of rice. Rice production is related with paddy farming condition. Indonesia paddy production reached the peak in 1984, caused by the green revolution on adoption of input production technology. But, after three decades, paddy productivity tended to decrease in line with the deminishing return of production. Even though the yield area and production increased, the return decreased.

In average, Indonesia paddy production in 1993 until 2015 increased to 57 million tons from 48 million The paddy productivity in average was 4,66 tons/are, even though, in the last three years the productivity increased (BPS, 2016). Compared with paddy productivities in Japan which was 6,65 ton/are and in Cina which was 6,35 ton/are ( FAO, 1993) paddy's productivity in Indonesia could be increasing in future. The conditions reflect that the actual paddy productivity in Indonesia appears to be close to the potential production. In other condition, the size of irrigated land area tend to continuously decrease significantly in the last decade from 10,7 million are in 2000 to be 7,8 million are in 2011 . 
The fragmented land area for growing paddy, limited access to capital for input production, inadequate maintenance of irrigation infrastructure and also farming institution to renew technology development restrict the paddy productivity at upstream. Development of the new technology on input production such us hybrid seed, organic fertilizer for minimizing land degradation, and minimum water management for paddy farming are also important to improve productivity. In other condition, paddy farming depends on climate circumstance.

The climate changes will influence directly to the productivity. The climate changes are so dynamic with new phenomenon in the different time and duration. At the last three decades, Indonesia could either not avoid the climate phenomenon change called El Nino (6 times) at dry season and La Nina (4 times) at rainy season (Irawan, 2006). The extreme climate will lay pressures to the paddy production system. It is necessary to make certain that the paddy production will be able to fulfill food sovereignty. Government has rules to ensure the paddy production needs and regulate the system to support paddy farming, especially facing the climate changing.

The main purpose of this paper is to focus on the impact of extreme climate to rice production. It is also concerned with government regulation supporting paddy farming system, what action needs to take to increase the availability, and fulfill food sovereignty especially at the climate change circumstance. The study also pays attention to how important it is to establish farmer institutions as the primary participants for paddy production system.

\section{The Method}

The data observation involved secondary data of rice production during 1980 - 2011, extreme climate occurance on that duration (Table 1), and also the government policy related with support to food sovereignty. Analysis method to achieve the main purpose is descriptive statistic with depth analysis. The impact of extreme climate to rice production was arranged with OLS (ordinary Least Squares) approach. The model runs El Nino (D1) and La Nina (D2) as dummy independent variables with the rice production as dependent variable. The model is formulated as follows:

with:

a $\quad=$ constanta

$\mathrm{b} 1, \mathrm{~b} 2=$ coefficient

D1, D2 = El Nino, La Nina

\section{Result and Discussion}

\section{The impact of climate extreme to rice production}

Agriculture activities cannot be separated from environment condition. Nature phenomenon has more important role lately, mostly climate anomaly called El Nino and La Nina. According to Australian Bureau of Meteorology (2012) El Nino and La Nina events are a natural part of the global climate system. They occur when the Pacific Ocean and the atmosphere above it change from their natural (normal) state for several seasons. El Nino events are associated with a warming of the central and eastern tropical Pacific, while La Nina events are the reverse, with a sustained cooling of these same areas. On tropical countries like Indonesia, both of those anomalies usually disclose the rainy pattern budge, temperature, and also the duration on dry session or rainy session. Then they could impact on fire of forest in sensitive area, flood, and enhance the attack of plant agitate organism and plant diseases.

El Nino phenomenon is characterized by decreasing of rainfall for long duration, meanwhile La Nina is characterized contrary by the rainfall increasing. El Nino causes the damage in food production. El Nino and La Nina could pose negative or positive impact on food production with different level depending on geographical position or province. In general, the variation level of impact is caused by (a) the impact of anomaly climate change

JoFSA Vol. 1, No. 1, April $2017: 41-46$ 
toward local climate situation or local rainfall, (b) farmers' ability to maximize production declines because of anomaly climate in each area (IPCC, 2006). Table 1 showed the rice production and climate extreme in Indonesia during 1980-2011.

Table1. Rice production and climate extreme in Indonesia during 1980-2011

\begin{tabular}{|c|c|c|c|c|}
\hline \multirow[b]{2}{*}{ No } & \multirow[b]{2}{*}{ Year } & \multirow[b]{2}{*}{ Rice Production (000 ton) } & \multicolumn{2}{|c|}{ Climate $*)$} \\
\hline & & & El nino & La nina \\
\hline 1 & 1980 & 20,574 & 0 & 0 \\
\hline 2 & 1981 & 22,287 & 0 & 0 \\
\hline 3 & 1982 & 23,191 & 1 & 0 \\
\hline 4 & 1983 & 25,932 & 1 & 0 \\
\hline 5 & 1984 & 24,006 & 0 & 0 \\
\hline 6 & 1985 & 26,542 & 0 & 0 \\
\hline 7 & 1986 & 27,014 & 1 & 0 \\
\hline 8 & 1987 & 27,253 & 1 & 0 \\
\hline 9 & 1988 & 28,340 & 0 & 1 \\
\hline 10 & 1989 & 29,072 & 0 & 1 \\
\hline 11 & 1990 & 28,453 & 0 & 0 \\
\hline 12 & 1991 & 28,187 & 1 & 0 \\
\hline 13 & 1992 & 30,358 & 1 & 0 \\
\hline 14 & 1993 & 30,320 & 1 & 0 \\
\hline 15 & 1994 & 29,417 & 1 & 0 \\
\hline 16 & 1995 & 31,349 & 0 & 0 \\
\hline 17 & 1996 & 32,215 & 0 & 0 \\
\hline 18 & 1997 & 31,093 & 1 & 0 \\
\hline 19 & 1998 & 31,040 & 1 & 1 \\
\hline 20 & 1999 & 32,031 & 0 & 1 \\
\hline 21 & 2000 & 32,693 & 0 & 1 \\
\hline 22 & 2001 & 31,806 & 0 & 0 \\
\hline 23 & 2002 & 32,444 & 0 & 0 \\
\hline 24 & 2003 & 32,861 & 0 & 0 \\
\hline 25 & 2004 & 34,102 & 0 & 0 \\
\hline 26 & 2005 & 34,028 & 0 & 0 \\
\hline 27 & 2006 & 34,600 & 0 & 0 \\
\hline 28 & 2007 & 36,970 & 0 & 0 \\
\hline 29 & 2008 & 38,078 & 0 & 0 \\
\hline 30 & 2009 & 40,656 & 0 & 0 \\
\hline 31 & 2010 & 42,436 & 0 & 1 \\
\hline 32 & 2011 & 41,326 & 0 & 1 \\
\hline
\end{tabular}

Source: Indonesia Statistic Centre Bureau, 2011

*) Indonesia Meteorology, Klimatology, and Geofisika Bureau, 2012

The analysis model of the rice production associated with El Nino or La Nina events occurred in Indonesia was arranged with OLS (ordinary Least Squares) approach. The model runs El Nino (D1) and La Nina (D2) as dummy independent variables with the rice production 
as dependent variable. Statistically, this model is qualified as good fit model and also appropriate with the natural theory (Table 2).

Table 2. The OLS approach impact of climate exstreme toward rice production

\begin{tabular}{lc}
\hline Multiple R & 0.41 \\
R Square & 0.17 \\
Adjusted R Square & 0.11 \\
Standard Error & 4963.45 \\
Observations & 32 \\
\hline
\end{tabular}

ANOVA

\begin{tabular}{lccccc}
\hline & $d f$ & $S S$ & $M S$ & $F$ & Significance $F$ \\
\hline Regression & 2 & $1.44 \mathrm{E}+08$ & 71976297 & 2.92 & 0.06 \\
Residual & 29 & $7.14 \mathrm{E}+08$ & 24635838 & & \\
Total & 31 & $8.58 \mathrm{E}+08$ & & \\
\hline & Coefficients & Standard Error & $t$ Stat & P-value \\
\hline Intercept & 31313.05 & 1211.58 & 25.84 & $1.43 \mathrm{E}-21$ \\
D1 & -3232.25 & 1929.51 & -1.67 & 0.10 \\
D2 & 2996.98 & 2163.41 & 1.385 & 0.17 \\
\hline
\end{tabular}

The result formulated as follows:

$\mathrm{Y}=31.313-3.232 \mathrm{D} 1+2.996 \mathrm{D} 2$

The result showed that climate extreme have negative and positive impact. The dummy coefficient means the different condition of rice production with or without El Nino or La Nina events. El Nino has negative impact to rice production, opposite with La Nina events. El Nino occurrences would be declining the rice production, meanwhile La Nina could enhance rice production. The different size of El Nino and La Nina impact is explained from the coefficient. This result is also supported by Irawan research in 2006. The failure of harvesting caused by El Nino drives food production down to $3,06 \%$, and $2,43 \%$ for wet paddy. Contrary with La Nina phenomenon, because the volume of rainfall could increase the food production up to $1,08 \%$, and $0,61 \%$ on wet paddy. Only La Nina in 1975 and 1998 caused the decreasing food production (Irawan, 2006).

Refer to Arifin (2010a), anomaly of extreme rainfall will bother agriculture activity, especially for paddy and grain. Higher rainfall boosts the flood possibility at wet land nearly $3 \%$ and the harvest failure reaches almost $14 \%$. In the meantime, the dry season will increase land drying at wet land for almost $8 \%$ and harvest failure for about 2\%. In general, Irsal Las, et al (2009) in Arifin (2010) revealed that extreme climate possibibly declined food production until $10 \%$ if the nation didn't take any measure. Based on the analysis, it is important to develop the awareness toward extreme climate, especially for everyone who was involved as stakeholders in agriculture activities.

\section{Government policy facing extreme climate}

Indonesian government is also concerned with food production and distribution, especially with rice availability. Government issued food policy during 2009-2011 consisting of at least three main points. Firstly, it issued Presidential Instruction No. 7 in 2009 about rice policy. Secondly, it issued Presidential Instruction No. 5 in 2011 about rice production safety ahead of extreme climate changes. And then the third was issuing Presidential Instruction No. 8 at 2011 about government arrangement on buffer stock of rice. All those policies were arranged to maintain the goal of rice sufficiency with 10 million ton production in 2014. 
Government set up the policy facing the climate extreme events to strengthen the effort supporting rice production safety. Presidential Instruction No. 5 was published on March 2, 2011. Instruction is directed to take necessary measures in a coordinated and integrated way in accordance with duties, functions, and their respective authorities to secure the production of paddy/rice and anticipated national and quick response to face extreme climate conditions. In particular, the Ministry of Agriculture in addition to focusing on risk analysis of extreme climate impacts on production and distribution of paddy/rice is also working to improve rice production systems by farmers through improved provision of production inputs (seeds, fertilizers, and pesticides), improved post-harvest activities, increased land area and irrigation management, field officers performance improvement, as well as strengthening the reserves of grain/rice at the level of government and society.

Other ministerial departments that play an important role in supporting the condition of infrastructure and facilitation of farming and the distribution of grain/rice are the Ministry of Public Works and the Ministry of Commerce. Ministry of Public Works must improve and develop the infrastructure function in supporting the development of rice farming and also providing support in improving the management of irrigation water for rice farming. Meanwhile, the Commerce Ministry is in charge of improving the supply and distribution of grain reserves and rice distribution system, including transporting grain/rice surplus areas to deficit areas. This task is certainly not meant as an instrument of justification means to import rice.

\section{Implementing the policy}

Presidential Instruction No. 52011 prevails for almost a year. Government awareness to anticipate the damage or failure on food production toward climate extreme is quite good. But, the effectiveness could not be evaluated soon. The damage and paddy harvest failure by the climate extreme reportedly caused the production to decrease for almost 4,95\%. The Coodinator Ministry of Economic report (2011) revealed that paddy production in 2011 reached 65,39 million tons. It means the production decresed 1,63\% campared with that of 2010 . The production was 4,95\% lower than Ministry of Agriculture target in 2011 which was almost 68,80 million tons. The decline of production was primarily caused by: a) extreme climate at plant season Juni-Agustus 2011, b) the size of yield harvest area attacked by plant rouse organism (620.807 are) and dry season (38.067 are), and c) the size of dried land amounting to 169.904 was higher than 2010 which was only 94.480 are. Dry season gave more disadvantage compared with rainy season on the same period, and also the budge of plant season in several paddy production centre from October to November 2011. Government is preparing the recovery budget for the failure of paddy production with fund of almost Rp 2 triliun.

Spesifically, Presidential Intruction No. 5, 2011 was concerned with minimizing the negative impact of extreme climate by focusing on currative and spatial approach as non price policy. This policy as complement to other policies (No. 7, 2009 and No. 8, 2011) cannot stand by itself. The complexity of paddy production system needs comprehensif and integrated policy, primary to reach the target production in 2014. It raises question as to whether the target in 2014 wasrealistic. Only less than 2 years. The succesfull of implementation of all those policies in field must be synergic with participation of every single stakeholders in paddy farming system. Sawit (2007) revealed that paddy/rice holds very strategic key in agricultural development especially in rural area. It is important to pay full and careful attention on paddy/rice agribusiness system, also avoid the bias on short term.

So, the next important step is to establish the farmer institution. The key of success in implementing the policy is really concerned with the farmers institution. The effort for strenghthening the paddy farming system cannot be separated from farmers empowerment. Improvement of farmers capacity on input management, adoption of production technology, capital access, and also establishment of the rule of agriculture institution are important to improve the paddy productivity and escape from the classical poverty problem. 
Development means process involving social, economic, and institustional, including all effort to get the better life and welfare (Todaro, 2000). So, developing the paddys farming to improve the productivity is important to synergize all those aspects. Agriculture development is also defined as a process of social change. The implementation is not only for welfare but also for developing human resources in economic, social, politic, culture, and neighborhoods by improvement, growth, and change.

Government needs to arrange the policy on long term and sustainable solution. Roadmap of farmer empowerment and capacity strengthening by adoption of new innovation and technology could possibly improve the paddy productivity significantly and reach the target of 10 million surplus in 2014. Farmer strengthening programs includes technology, capital access, and also assistances on all of the farming process. Arifin (2010b) also declared that adoption process and agriculture innovation adapted must be accompanied by institution innovation, value system change, efficiency level, income enhancement, and also significant improvement of farmer welfare will be able to solve the main problem at the upstream of paddy farming system.

\section{Conclution and Suggestion}

\section{Conclution}

The extreme climate have negative and positive impact. El Nino usually has negative impact to rice production, opposite with La Nina events. The different size of El Nino and La Nina impact could be explained from the coefficient.

The key of success in implementing the policy is really concerned with the farmers institution. The effort should integrate action on improvement of farmers capacity on input management, adoption of production technology, capital access, and also establishment of the rule of agriculture institution.

\section{Suggestion}

Government needs integrated action on implementing the policies and actively involving every stakeholder in paddy/rice agribusiness system. To minimize the negative impact of extreme climate, not only government but also the farmers need to be adaptable to every change. It needs support through farming technology based on durable seed on dry land or minimum water. Farmer institution strengthening will improve the ability and awareness to maximum level and avoid the damage and disadvantage caused by extreme climate.

\section{Reference}

Arifin B. 2010a. The Future of Agriculture in Climate Change Era. Kompas. 18 October 2010. 2010b. Innovation for Productivity. Kompas. 5 July 2010.

Australian Government Bureau of Meteorology. 2012. Record-Breaking La Nina Events. [online; cited July 2012] Available from URL: www.bom.gov.au

Coordinator Ministry of Economic Department. 2011. Annual Accountability Report. Coordinator Ministry of Economic Department, Jakarta

FAO. 1993. Rice In human Nutrition. Food and Nutrition Series. FAO, Rome

Indonesia Statistic Bureau, 2011. Indonesia Statistic. Central BPS. Jakarta 2016. Indonesia Statistic. Central BPS. Jakarta

IPCC (Intergovernmental Panel on Climate Chang). 2001. Climate Change 2001. Impact. Adaptation. and Vulnerability. Cambridge. UK. Cambride University Press.

Irawan B. 2006, Fenomena Anomali Iklim El Nino dan La Nina: Kecenderungan Jangka Panjang dan Pengaruhnya pada P Pangan. Forum Penelitian Agro Ekonomi. 24(1): 28-45.

Sawit M. Husein. 2007. The World Rice Policy Purposes: The wrong recipe. Mubyarto article. Todaro, Michael P. 2000. The Third Wold Economic Development. Erlangga Publisher. Jakarta. 